\title{
Peranan Pendidikan Agama Islam Dalam Upaya Internalisasi Karakter Di Pondok Pesantren Nihayatul Amal Rawamerta Karawang
}

\author{
Khalid Ramdhani ${ }^{1 *}$ \\ Kasja Eki Waluyo \\ *IUniversitas Singaperbangsa Karawang, Jawa Barat, Indonesia \\ 2Universitas Singaperbangsa Karawang, Jawa Barat, Indonesia \\ khalid.ramdhani@fai.unsika.ac.idk.ekiwaluyo@gmail.com
}

\begin{abstract}
Abstrak
Seluruh elemen mengakui bahwa pendidikan karakter dalam era milenial serba digital ini sangat penting dan relevan untuk diaplikasikan diseluruh jenjang pendidikan untuk mengatasi dekadensi moral yang mewabah di nusantara ini. Krisis tersebut antara lain menururunnya sopan santun anak-anak dan remaja kepada orang yang lebih tua, siswa berani melawan guru di sekolah, pergaulan bebas (free sex), meningkatnya kejahatan terhadap teman sejawat, menyebarnya prilaku konsumtif narkoba dan menonton film pornografi dan sering kita jumpai masalah-masalah social yang terjadi pada anak-anak usia sekolah baik di perkotaan ataupun di pedesaan sekalipun, hal tersebut belum dapat diatasi secara menyeluruh. Oleh karena itu di sini membentuk karakter anak sangatlah penting. Terutama peran guru di sekolah/pondok pesantren untuk mencetak generasi berkarakter dalam kehidupan masyarakat. Semakin banyak generasi berkaraker niscaya kebangkitan suatu bangsa dari kemerosotan akan tercapai.

Penelitian ini bertujuan untuk mendeskripsikan seberapa besar peranan pembelajaran Pendidikan Agama Islam di pondok pesantren Nihayatul Amal dalam upaya untuk menanamkan dan membentuk karakter-karakter sesuai dengan karakter bangsa Indonesia yang dilakukan oleh para santri dan santriwati dalam kegiatan sehari - hari.

Penelitian ini menggunakan pendekatan kualitatif dengan metode yang digunakan yaitu metode studi kasus. Penelitin ini dilakukan dengan subyek penelitian santri dan santriwati Pondok Pesantren Nihayatul Amal Rawa Merta Karawang. Pengumpulan data dilakukan dengan observasi, catatan lapangan, wawancara dan dokumentasi.

Dari hasil penelitian ini peneliti berharap agar dapat memberikan kontribusi dan manfaat bagi semua pihak-pihak yang terkait, terutama pihak pondok pesantren dalam rangka menanamkan dan membentuk karakter santri sesuai dengan karakter bangsa Indonesia dan khususya sesuai dengan ajaran agama Islam sehingga dapat bermanfaat juga bagi sekolah/pondok pesantren lain pada umumnya.
\end{abstract}

Kata Kunci: Pendidikan Agama Islam, Internalisasi Karakter, Pondok Pesantren

\begin{abstract}
All elements acknowledge that character education in this digital all-millennial era is very important and relevant to be applied throughout all levels of education to overcome the moral decadence that is endemic in this archipelago. These crises include the decline in the courtesy of children and adolescents to older people, students brave against teachers at school, promiscuity (free sex), increased crime against peers, the spread of consumptive behavior and watching pornographic films and we often meet social problems that occur in school-age children both in urban and rural areas, even though this has not been resolved as a whole. Therefore here shaping the character of children is very important. Especially the role of teachers in schools / Islamic boarding schools to produce a generation of character in community life. More and more generations berkaraker undoubtedly the rise of a nation from a decline will be achieved.

This study aims to describe how large the role of Islamic Religious Education learning in Nihayatul Amal Islamic boarding schools is in an effort to instill and shape characters in accordance with the character of the Indonesian nation carried out by the students and female students in their daily activities.

This research uses a qualitative approach with the method used is the case study method. This research was conducted with research subjects of students and female students of Nihayatul Amal Rawa Merta Islamic Boarding School in Karawang. Data collection is done by observation, field notes, interviews and documentation.

From the results of this study the researchers hope to be able to contribute and benefit to all parties concerned, especially the boarding school in order to instill and shape the character of students in accordance with the character of the Indonesian nation and specifically in accordance with the teachings of Islam so that it can also benefit the school / other boarding schools in general.
\end{abstract}

Keywords: Islamic Education, Character Internalization, Islamic Boarding School 


\section{PENDAHULUAN}

Pendidikan merupakan hal penting dalam kehidupan manusia. Tidak mengherankan jika semua elemen masyarakat dari kalangan awam hingga para ilmuwan ikut serta memperbincangkannya. Semakin kacau problematika yang dihadapi dalam ranah pendidikan, semakin ramai juga orang-orang ikut membahasnya. Dalam kajian-kajian lingkup regional masyarakat, guru ataupun mahasiswa hingga lingkup internasional yang diadakan dalam acara-acara resmi para kaum intelektual di berbagai daerah. Idealnya pendidikan memberikan andil besar dalam memberi solusi terhadap krisis kemanusiaan yang kini melanda kehidupan. Mulai pendidikan, kita ingin menghasilkan manusia yang jujur, bersemangat, pekerja keras, tidak malas, berani, kreatif, cinta kebersihan, toleran dan sebaginya. Ini membuktikan bahwa tingkat urgensitas pendidikan sangat tinggi dalam benak setiap manusia. Dengan proses pendidikan yang baik dengan keluasan ilmu, setiap individu manusia dapat mencapai derajat yang mulia dalam pandangn Allah juga pandangn manusia. Sebagaimana firman Allah Swt dalam surat Al Mujaddalah : II yang berbunyi:

Hai orang-orang beriman apabila kamu dikatakan kepadamu: "Berlapang-lapanglah dalam majlis", Maka lapangkanlah niscaya Allah akan memberi kelapangan untukmu. dan apabila dikatakan: "Berdirilah kamu", Maka berdirilah, niscaya Allah akan meninggikan orang-orang yang beriman di antaramu dan orang-orang yang diberi ilmu pengetahuan beberapa derajat. dan Allah Maha mengetahui apa yang kamu kerjakan.

Namun untuk meraih derajat yang mulia tersebut tentu tidak mudah semudah mengedipkan 196) bahwa klasifikasi tidak sama artinya dengan dikotomi. Klasifikasi hanya bersifat kepada pembagian, lain halnya dengan dikotomi, ia menunjukan kepada pemisahan terhadap sesuatu. Dari uraian ini, menurut kelopak mata. Tentu tidak. Butuh waktu yang tidak singkat dalam proses pembelajaran bagi seorang manusia. Butuh perjuangan cerdas dalam menuntut ilmu dari diri seorang anak. Berdasar kepada Uud Republik Indonesia No : 20 tahun 2003 tentang system pendidikan nasional dinyatakan bahwa pendidikan adalah usaha sadar dan terencana untuk mewujudkan suasana belajar dan proses pembelajaran agar peserta didik secara aktif mengembangkan potensi dirinya untuk memiliki kekuatan spiritual keagamaan, pengendalian diri, kepribadian, kecerdasan, akhlak mulia, serta keterampilan yang diperlukan dirinya, masyarakat, bangsa dan negara. Itulah yang dicitacitakan oleh bangsa Indoensia. Maka dari pada itu Negara dengan pasal 6 ayat I UU No 20 Tahun 2003 mewajibkan setiap warga negaranya dengan usia wajib belajar 7 s.d. 15 tahun untuk menuntut ilmu. Bahkan dalam Islam, Rasulullah menganjurkan umatnya untuk menuntut ilmu sampai akhir hayat tanpa batas ruang dan waktu sebagaiaman hadist Rasulullah Saw :

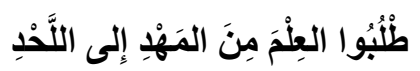

"Tuntutlah ilmu sejak dari buaian hingga liang lahat"

Tentu perlu penekanan dalam klasifikasi mempelajari suatu ilmu. IImu apa saja yang tingkat keharusannya paling tinggi atau bisa dikatakan wajib dipelajari. Penting atau tidaknya, perlu tidak perlunya harus dikaji lebih dalam sesuai dengan kebutuhan seseorang khususnya sebagai seorang muslim umat dari Nabi Muhammad Saw. Dalam hal ini, Imam Ghazali yang digelari sebagai pemebela Islam (hujjatul Islam)mengklasifikasikan ilmu ke dalam dua bagian. Perlu untuk dicatat, menurut Baharudin dkk (201l : beberapa peneliti bahwa Al Ghazali sangat terkenal dengan tokoh yang telah mengemukakan seputar dikotomi ilmu. Dalam hal ini secara sederhana klasifikasi ilmu menurut Imam Ghazali dapat 
diklasifikasikan kedalam dua klasifikasi. Pertama adalah ilmu agama yang bersifat fardhu a'in dan yang kedua adalah ilmu umum yang bersifat fadhu kifayyah. Berkenaan dengan hal tersebut, peneliti dalam tulisan ini akan mencoba mengulas pendidikan agama islam yang bersinergi untuk menghasilkan karakter-karakter baik (good character).

Di era milenial saat ini, membentuk seorang anak menjadi manusia berkarakter dan berkualitas bukanlah hal mudah seperti membalikan tangan. Butuh program, proses panjang, rencana matang, perjuangan tiada dan integritas yang kuat antara tiga domain utama dalam dunia pendidikanya itu keluarga, sekolah dan masyarakat, serta evaluasi atas ketercapaian visi misi tersebut.

Proses internalisasi karakter dapat dilakukan dengan baik jika seluruh stakeholder memahami betul akan urgensitas pembentukan karakter bagi peserta didik. Kesembilan karakter dasar yang digagas pemerintah selayaknya lembaga pendidikan mampu menginternalisasikannya kepada sanubari seluruh peserta didik. Karakter-karakter itu berguna bagi mereka dalam kehidupan bermasyarakat luas.

Pendidikan agama Islam mempunyai dua aspek terpenting. Aspek pertama adalah yang ditujukan kepada jiwa atau pembentukan kepribadian. Anak didik diberi kesadaran kepada adanya tuhan, lalu dibiasakan melakukan perintah - perintah tuhan dan meninggalkan larangan - larangannya . Aspek kedua adalah yang ditujukan kepada pikiran yaitu pengajaran agama itu sendiri, kepercayaan kepada Tuhan tidak akan sempurna bila isi dari ajaran - ajaran Tuhan itu tidak di ketahui betul - betul. (Zakiah Drajat, "Kesehatan Mental”,( Jakarta : Toko Gunung Agung, 200I). Dengan demikian dapat disimpulkan bahwa peranan pendidikan agama sangatlah penting dalam menanamkan dan membentuk karakter yang baik (good character) bagi generasi muda.

\section{METODOLOGI PENELITIAN}

Penelitian ini merupakan studi lapangan (field research) dan studi pustaka (library research) dengan menggunakan pendekatan kualitatif. Penelitian kualitatif dalam Herdiansyah (2010 : 8) adalah suatu prosedur penelitian yang menghasilkan data deskriptif, berupa data-data tertulis atau lisan dari orang-orang dan karakter yang dapat diamati sebagai objek penelitian.

Sedangkan metode penelitian yang penulis gunakan adalah metode penelitian deskriptif, Menurut Lexy J. Moloeng (1997 : 9) yaitu untuk membuat deskripsi, gambaran, atau lukisan secara sistematis, factual dan akurat mengenai fakta-fakta, sifat-sifat serta hubungan antar fenomena yang diselidiki untuk menggambarkan atau menganalisis suatu hasil penelitian tetapi tidak digunakan untuk membuat kesimpulan yang lebih luas.

Teknik pengumpulan data Untuk memperoleh data yang dikehendaki sesuai dengan permasalahan dalam penelitian ini, maka teknik pengumpulan data dengan menggunakan triangulasi yaitu observasi, wawancara dan studi dokumentasi.

\section{PEMBAHASAN DAN HASIL PENELITIAN}

\section{Pengertian Pendidikan Agama}

Istilah pendidikan berasal dari kata didik dengan memberinya awalan "pe" dan akhiran "kan" mengandung arti perbuatan (hal, cara dan sebagainya) istilah pendidikan ini semula berasal dari bahasa yunani, yaitu "paedagogik " yaitu berarti bimbingan yang di berikan kepada anak. Istilah ini kmudian di terjemahkan kedalam bahasa inggris dengan education yang berarti pngembangan atau bimbingan. Dalam bahasa arab 
istilah ini sering di terjemahkan dengan tarbiyyah yang berarti pendidikan. Ahmad Marimba dalam Ramayulis (2004 : I) mengatakan bahwa pendidikan adalah bimbingan atau pimpinan yang di lakukan secara sadar oleh si pendidik terhadap perkembangan jasmani dan rohani si terdidik menuju terbentuknya kepribadian yang utama.

Dalam Islam, menurut Hery Nur Aly (1999 : 3) sekurang-kurangnya terdapat tiga istilah yang digunakan untuk menandai konsep pendidikan, yaitu pertama tarbiyah, kedua ta`lim, dan ketiga adalah ta'dib. Namun istilah yang sekarang berkembang di dunia Arab adalah tarbiyah. Sedangkan menurut $\mathrm{Ki}$ Hajar Dewantara dalam Hasbullah (2005 : 4) pendidikan yaitu tuntunan di dalam hidup tumbuhnya anak-anak, adapun maksudnya pendidikan yaitu menuntun kekuatan kodrat yang ada pada anak-anak itu, agar mereka sebagai manusia dan sebagai anggota masyarakat dapatlah mencapai keselamatan dan kebahagiaan setinggi-tingginya.

Menurut Dzakiah Dradjat (1992 : 86) pendidikan Agama Islam adalah pendidikan dengan melalui ajaran - ajaran agama islam, yaitu berupa bimbingan dan asuhan terhadap anak didik agar nantinya setelah selesai dari pendidikan ia dapat memahami, menghayati dan mengamalkan ajaran ajaran agama islam yang telah di yakininya secara menyeluruh, serta menjadikan ajaran agama islam itu sebagai suatu pandangan hidupnya demi keselamatan dan kesejahteraan hidup di dunia dan di akhirat kelak.

Menurut Zuharismi bahwa pendidikan Agama Islam berarti usaha-usaha secara sistematis dan pragmatis dalam membantu anak didik agar mereka hidup sesuai dengan ajaran Islam (1983 : 27). Adapun Ahmad Tafsir dalam bukunya mengatakan pendidikan Agama Islam adalah usaha sadar untuk menyiapkan siswa agar memahami (knowing), terampil melakukan (doing), dan mengamalkan (being) agama Islam melalui kegiatan pendidikan, agar menjadi orang yang taat beragama, berilmu dan beramal sesuai ajaran Agama Islam (2008 : 44). Guru Agama dalam kamus besar bahasa Indonesia adalah guru yang mengajarkan mata pelajaran agama. Jadi Guru Pendidikan Agama Islam adalah guru yang mengajarkan mata pelajaran Agama Islam. Guru Agama Islam bertanggung jawab terhadap pembinaan watak, kepribadian, keimanan, dan ketakwaan siswa di sekolah. Guru pendidikan Islam dapat dikategorikan sebagai guru, ustadz/ustadzah dan kiai.

Dari pendapat di atas dapat disimpulkan bahwa pendidikan agama islam adalah suatu proses bimbingan jasmani dan rohani yang berlandaskan ajaran islam dan dilakukan dengan kesadaran untuk mengembangkan potensi anak menuju perkembannga yang maksimal, sehingga terbentuk kepribadian yang memiliki nilai-nilai islam.

\section{Konsep Internalisasi}

Internalisasi secara epistemology berasal dari kata intern atau internal yang bermakna bagian dalam atau menempatkan dalam kepemilikan, kemudian dalam kaidah bahasa Indonesia akhiran si berarti menunjukkan proses. Dalam kamus besar bahasa Indonesia (1989 : 336) Internalisasi diartikan sebagai penghayatan, penugasan, penguasaan secara mendalam yang berlangsung melalui pembinaan, bimbingan, penyuluhan, penataran, dan sebagainya.

Dalam kamus psikologi (1993: 256) internalisasi mempunyai arti penyatuan sikap atau penggabungan, standart tingkah laku, pendapat, dalam kepribadian. Freud (1993 : 256) menyakini bahwa super ego atau aspek moral kepribadian berasal dari internalisasi sikap-sikap orang tua. Sedangkan menurut Mulyasa (2012 : 147) internalisasi yaitu upaya 
menghayati dan mendalami nilai, agar tertanam dalam diri setiap manusia.

Dengan demikan dapat disimpulkan bahwa Internalisasi merupakan suatu proses penanaman sikap ke dalam diri pribadi seseorang melalui pembinaan, bimbingan dan sebagainya agar ego menguasai dan menghayati secara mendalam suatu nilai, sehingga dapat tercermin dalam sikap dan tingkah laku sesuai dengan standart yang diharapkan.

Adapun proses internalisasi nilai-nilai menurut Thomas Lickona (2012 : 83) karakter yang tepat untuk pendidikan nilai terdiri dari nilai operatif dan nilai dalam tindakan. Proses nilai-nilai karakter menjadi sebuah kebaikan merupakan disposisi batin yang ditanggapi dengan cara yang menurut moral itu baik. Nilai Karakter tersebut memiliki tiga bagian yang saling berhubungan yaitu : pengetahuan moral, perasaan moral dan prilaku moral.

Lickona (2012:84) menambahkan bahwa pengetahuan moral terdiri dari: Kesadaranmoral, pengetahuan nilai moral, penentuan presfektif, pemikiran moral, pengambilan keputusan dan pengetahuan pribadi. Perasaan moral meliputi : Hati nurani,harga diri, empati, mencintai hal yang baik, kendali diri dan kerendahan hati. Tindakan Moral meliputi: kompetensi, keinginan dan kebiasaan. Dari penjelasan tersebut bisa dilihat dalam bentuk diagram sebagai berikut:

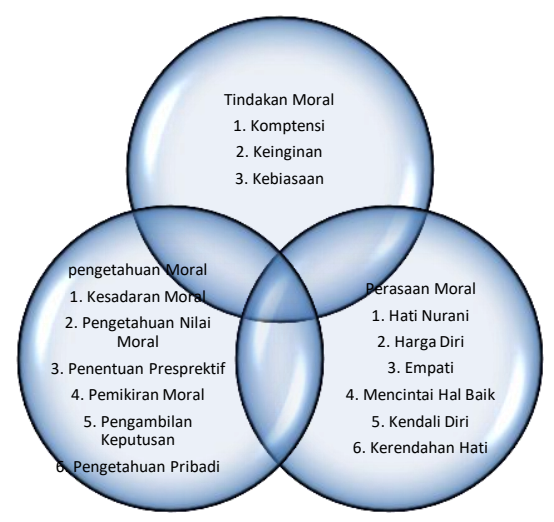

\section{I Diagram Komponen karakter baik}

Seluruh dimensi diagram tersebut saling berhubungan dengan masing-masing domain karakter yang menunjukkan bahwa ketiga domain tersebut saling berhubungan antara satu dengan yang lain. Penilaian moral dan perasaan morah cukup mempengaruhi prilaku moral, dan pengaruh tersebut bersifat resiprokal : bagaimana kita berprilaku juga mempengaruhi bagaimana kita berfikir dan merasa (seperti, ketika kita memaafkan dan bertingkah laku terhadap seseorang yang kita marahi, kita biasanya mendapati pemikiran dan perasaan kita yang berhubungan dengan orang tersebut menjadi lebih positif). (2012:85)

\section{Pengertian Karakter}

Secara etimologis, kata karakter menurut Ryan dan Bohlin dalam Suyadi (inggris: character) berasal dari bahasa Yunani yang berarti "to engrave” . Kata to engrave itu sendiri dapat diterjemahkan menjadi mengukir, melukis, memahatkan dan menggoreskan. Berbeda dengan bahasa inggris, dalam bahasa Indonesia yang dikutip dari Pusat Bahasa Depdiknas kata "karakter" dapat diartikan sebagai tabiat, sifat-sifat kejiwaan, akhlak atau budi pekerti yang membedakan seseorang dengan yang lain. Artinya, orang yang berkarakter adalah orang yang berkepribadian, berperilaku, bersifat, bertabiat atau berwatak tertentu dan watak tersebut yang membedakan dirinya dengan orang lain. (Suyadi, Strategi Pembelajaran Pendidikan Karakter", (Bandung : Rosda Karya, 5)

Karakter berasal dari nilai tentang sesuatu. Suatu nilai yang diwujudkan dalam bentuk perilaku anak itulah yang disebut karakter. Jadi suatu karakter melekat dengan nilai dari perilaku tersebut. Karena tidak ada perilaku anak yang tidak bebas dari nilai. 
Hanya barangkali sejauhmana kita memahami nilai-nilai yang terkandung dalam perilaku seorang anak atau sekelompok anak memungkinkan berada dalam kondisi tidak jelas. (Dharma Kusuma dkk, Pendidikan Karakter Kajian Teori dan Praktik di Sekolah, (Bandung : Remaja Rosdakarya, II)

Karakter menurut Kepmendiknas adalah sebagai nilai-nilai yang khas baik (tahu kebaikan, mau berbuat baik, nyata berkehidupan baik, dan berdampak baik terhadap lingkungan) yang terpatri dalam dir dan terejawantahkan dalam perilkaku. Pertimbangan di atas juga dalam rangka mewujudkan bangsa yang berbudaya melalui pengauatan nilai-nilai religious, jujur, toleran, disiplin, bekerja keras, kratif, mandiri, demokratis, cinta damai, gemar membaca, peduli lingkungan, peduli social dan bertanggung jawab.

Karakater adalah kumpulan tata nilai yang menuju pada suatu sistem, yang melandasi pemikiran, sikap, dan perilaku yang ditampilkan. Sebagaimana menurut Zubaedi menyatakan bahwa "Pengertian karakter adalah bawaan, hati, jiwa, kepribadian, budi pekerti, perilaku, personalitas, sifat, tabiat, temperamen, dan watak Istilah karakter memiliki dua pengertian yaitu: I) ia menunjukkan bagaimana seseorang bertingkah laku. 2) istilah karakter erat kaitannya dengan (personality) Seseorang baru bisa disebut orang yang berkarakter (a person of character )apabila tingkah lakunya sesuai kaidah moral.2

Sedangkan Dharma Kesuma menyarankan bahwa: "Karakter sama dengan kepribadian. Kepribadian dianggap sebagai ciri, atau karakteristik, atau gaya, atau sifat khas dari diri seseorang yang bersumber dari bentukan-bentukan yang diterima dari lingkungan”.3Seseorang dianggap memiliki karakter mulia apabila mempunyai pengetahuan yang mendalam tentang potensi dirinya serta mampu mewujudkan potensi itu dalam sikap dan tingkahlakunya.
Dalam hal ini pemerintah memandang perlu pengutan pendidikan karakter, atas dasar pertimbangan presiden Joko Widodo pada 6 september 2017 menandatangani peraturan presiden (perpres) nomor : 87 tahun 2017 tentang Penguatan Pendidikan Karakter. Dalam perpres ini disebutkan, penguatan pendidikan karakter yang selanjutnya disingkat PPK adalah gerakan pendidikan di bawah tanggung jawab satuan pendidikan untuk memperkuat karakter peserta didik melalui harmonisasi olah hati, olah rasa, olah pikir dan olah raga dengan pelibatan dan kerjasama antara satuan pendidikan, keluarga dan masyarakat sebagai bagian dari Gerakan Nasional Revolusi Mental (GNRM). Jadi dapat disimpulkan Karakater adalah kumpulan tata nilai yang menuju pada suatu sistem, yang melandasi pemikiran.

\section{HASIL PENELITIAN}

\section{Potret Pondok Pesantren Nihayatul Amal}

Ponpes Nihayatul Amal berdiri tahun 1965 oleh bapak Husni Hamid yang kemudian di kelola dan di amanah kan kepada KH.Ahmad Bushaeri sebagai pimpinan dan pendiri ponpes. Bersama dengan tokoh agama dan aparat setempat KH.Ahmad Bushaeri membangun satu komplek Pesantren yang pada waktu itu masih berbasis Salafi. Kemudian Setelah Ponpes Putra masyhur didirikanlah Ponpes putri (Al-banat) pada tahun 1984. Setelah semakin berkembang KH.Mamduh Mastari meminta izin kepada KH.Ahmad Bushaeri untuk mendirikan Ponpes kanak-kanak Tarbiyatul Wildan Nihayatul Amal yang kemudian berdiri pada tahun 1992 yang terletak di dekat irigasi Rawamerta.

Setelah Ponpes kanak-kanak Tarbiyatul Wildan Nihayatul Amal Almarhun KH.Mamduh Mastari mendirikan Lembaga Pendidikan Formal yaitu MI Nihayatul Amal, pada tahun 1996. Menyusul dari itu 
SMP Nihayatul Amal berdiri pada tahun 2002 dan tak lama di tahun 2005 Berdirilah MA Nihayatul Amal dan SMK Nihayatul Amal pada tahun 2009.Semua lembaga pendidikan formal tersebut berada di bawah naungan Ponpes, Kecuali MTsN Rawamerta yang memang di kelola Pemerintah namun tidak lepas dari peran KH.Ahmad Bushaeri yang menjual tanah nya untuk membangun gedung milik sendiri yang sekarang terletak dekat dengan ponpes putri.

Di tahun 2006 Pendiri Ponpes KH.Ahmad Bushaeri jatuh sakit hingga akhirnya beliau di panggil untuk kembali oleh Allah S.W.T lahu alfaatihah. KH.Abdul Basith Bushaeri sebagai Putra pertama dari Alm KH.Ahmad Bushaeri meneruskan perjuangan sebagai Pimpinan Umum ponpes. semakin lama setelah KH.Ahmad Bushaeri tutup usia santri di Ponpes Nihayatul Amal semakin banyak dari berbagai penjuru indonesia.Banyak pula Alumni yang mendirikan cabang sebagai bentuk pengabdian terhadap almarhum.

Motto dari pondok pesantren Nihayatul Amal adalah Memelihara budaya-budaya klasik (ulama salaf) yang baik dan mengambil budaya-budaya baru yang konstruktif. Adapun Visi dari pondok pesantren Nihayatul Amal adalah Terwujudnya pondok pesantren yang kondusif dalam mencetak generasi santri yang cerdas, berfikir positif dan beramal sholeh. Berlandaskan Qur'an, Sunnah, ljma ulama dan Qias dengan menerapkan metode kajian kitab kuning (Salafiah). Sedangkan misi dari pondok pesantren Nihayatul Amal adalah I.Mencetak generasi muda yang berakhlakul karimah. 2.Mencetak generasi santri yang berilmu amaliyah dan beramal ilmiah sesuai kaidah ahli sunnah waljama'ah 3.Menanamkan kebiasaan islamiah dalam kehidupan sehari hari. 4.Menanamkan disiplin ibadah terhadap santri.

\section{Prioritas Pendidikan Nihaytul Amal}

Pesantren yang didirikan ini almagfurlah $\mathrm{KH}$ Ahmad Bushaeri tahun 1963 ini, sampai saat ini tetap eksis. Bahkan, sudah membuka cabang di luar Jawa seperti Lampung dan Kalimantan. Pimpinan PNA ke tiga saat ini setelah $\mathrm{KH}$ Abdul Bashit Bushaeri, $\mathrm{KH}$ Bubun Bunyamin Bushaeri mengatakan, dari dulu hingga sekarang, PNA tidak pernah lepas mengkaji kitab kuning, khususnya kitab Nahwu dan Shorof atau biasa di sebut ilmu alat. Karena ilmu tersebut merupakan dasar di mana santri atau siswa bisa membedah kitab-kitab lainnya.

Kitab alat yang dikaji seperti Jurumiyah, Imriti hingga Alfiyah. Adapun ilmu figh, tasawuf, ilmu Alquran, dan yang lainnya sebagai pelengkap. Karena dirinya menyebutkan, dengan mempelajari ilmu alat, merupakan awal pembuka santri untuk bisa membedah ilmu-ilmu lainnya. Dalam hal ini bukan berarti ilmu akidah dan akhlak tidak dipelajari, semua itu dipelajari namun dititik beratkan kepada mengaji alat (ilmu-ilmu tata bahasa arab) karena ilmu-ilmu tersebut bisa digunakan untuk membedah isi-isi kitab kuning laingnya. Hal itu penting, meskipun zaman semakin modern sebagaimana amanat para ulama jangan sampai meninggalkan kitab-kitab kuning di pesantren salaf.

\section{Pendidikan Agama Islam di Pondok Pesantren Nihayatul Amal Rawamerta}

Implementasi Pendidikan Agama Islam di Pondok Pesantren Nihayatul Amal menggunakan dibagi menjadi beberapa dimensi pembelejaran. Secara umum penerapan pendidikan agama islam di terbagi dua bagian. Perama pendidikan agama islam bermuatan materi berdasarkan materi-materi yang telah disusun oleh pemerintah pusat yang diajarkan di kelas-kelas secara formal. Kedua pendidikan agama islam yang 
berdasar dari kajian-kajian kitab klasik yang dipilihkan sesuai dengan kemampuan para santri dalam mempelajari kitab-kitab tersebut. Pengajian kitab klasik dilaksanakan diluar kelas secara formal. Biasa dilaksanakan di masjid dibagi per grup sesuai dengan tingkatan usia dan kelas para santri.

Pondok Pesantren Nihayatul Amal dalam porsi materi yang diajarkan kepada para santri lebih menekankan pendidikan agama islam sesuai dengan program yang dijungjungnya yaitu pembelajaran system model pesantren salafi yang berfokus pada dengan kitab-kitab klasik karya para ulama zaman terdahulu, namun tidak meninggalkan perkembangan zaman.

\section{Metode Pembelajaran Kitab Klasik di Pondok Pesantren Nihayatul Amal}

Mengingat urgensi dari pembelajaran Kitab Kuning di pondok pesantren, maka metode pembelajarannya pun mutlak perlu diperhatikan, sebab pembelajaran mesti disajikan dengan cara yang tepat agar tercapai tujuan pelajaran. Menurut Zamakhsyari Dhofier dan Nurcholish Madjid, metode pembelajaran Kitab Kuning di pesantren meliputi; metode sorogan, dan bandongan. Sedangkan Husein Muhammad menambahkan bahwa, selain metode yang diterapkan dalam pembelajaran Kitab Kuning adalah metode wetonan atau bandongan, dan metode sorogan, diterapkan juga metode diskusi (munazharah), metode evaluasi, dan metode hafalan.

Apabila diperhatikan metode pembelajaran kitab kuning yang digunakan Pesantren Pondok Pesantren Nihayatul Amal Rawamerta, kelihatannya tidak jauh berbeda dengan metode pembelajaran kitab kuning di pesantren lain di Nusantara (Jawamisalnya). Mereka menggunakan metode bandongan dan sorogan. Metode bandongan yang diterapkan Pesantren Pondok Pesantren Nihayatul Amal Rawamerta sesuai dengan pemikiran Zamakhsyari Dhofier dan Endang Turmudi. Menurut Zamakhsyari Dhofier, metode bandongan adalah penyampaian kitab dimana seorang guru, kiai, atau ustadz membacakan dan menjelaskan isi kitab, sementara santri, murid, atau siswa mendengarkan, memberikan makna, dan menerima." Sementara Endang Turmudi pula menyebutkan bahwa dalam metode ini kyai hanya membaca salah satu bagian dari sebuah bab dalam sebuah kitab, menerjemahkannya ke dalam bahasa Indonesia dan memberikan penjelasanpenjelasan yang diperlukan. Sedangkan pembelajaran kitab kuning dengan menggunakan metode sorogan yang diterapkan Pesantren Pondok Pesantren Nihayatul Amal Rawamerta sesuai dengan pemahaman Husein Muhammad, yaitu santri membaca sedangkan usutadz/ah mendengarkan sambil memberi catatan, komentar, atau bimbingan bila diperlukan.

\section{Karakter yang di internalisasikan terhadap} santri pesantren Nihayatul Amal Rawamerta

\section{Mandiri}

Secara umum kemandirian bisa dilihat dari tingkah laku, bentuk emosional dan sosial. Anak mampu berpisah dalam waktu singkat dengan orangtuanya, misalnya saat mulai bersekolah. Anak bisa masuk ke kelas dengan nyaman karena mampu mengontrol dirinya. Ini bentuk secara emosional. Kemudian secara sosial, anak tidak harus selalu berinteraksi dengan pengasuhnya. la bisa berhubungan dengan orang lain secara independen sebagai individu. Sejak usia dini, sekitar 2-3 tahun, anak sebetulnya sudah menunjukkan perilaku dasar mandiri. Orangtua bisa melihat keinginan mandiri itu dengan memperhatikan gejala yang ada.

Berdasarkan observasi di Pondok Pesantren Nihayatul Amal dengan melihat segala gejala-gejala yang ada. Santri-santri semenjak tingkat dasar, karakter 
kemandirian mereka di didik sedini mungkin. Tentu kita tahu seorang santri itu jauh dari orang tua dan harus bisa merawat diri nya sendiri tanpa harus di suruh-suruh. Di pesantren, sifat atau karakter mandiri adalah yang pertama harus di biasakan oleh seorang santri. Para pengurus tentunya hanya mengatur apa saja yang harus di lakukan oleh seorang santri baik di kamar maupun di luar kamar. Yang biasanya berangkat sekolah di siapkan oleh orang tua sekarang harus persiapan sendiri dan perihal yang lain juga.

Dalam pendidikan agama islam, santri-santri tampak menerapkan ilmu-ilmu yang telah mereka pelajari selama ini, baik dalam kelas secara formal ataupun di luar kelas secara non formal. Peran guru pendidikan agama islam sangat berperan penting dalam proses internalisasi karakter kemandirian. Karena ditahap awal proses internalisasi karakter, santri-santri memerlukan pengawasan ketat dari pihak guru pendidikan agama islam dengan pengurus asrama putra/putri.

Tak sedikit orangtua yang takut bila anaknya yang belasan tahun melakukan hal-hal tertentu. Saat anak memiliki motivasi tertentu dengan kemauannya sendiri, kerap tidak diperbolehkan, bahkan langsung dimarahi. Akibatnya, anak jadi penakut dan tak mampu mengontrol diri sendiri. Tak ada salahnya memperbolehkan anak naik-turun tangga sendiri, tentunya dengan diawasi dan dijaga oleh orangtua maupun pengasuhnya. Yang dapat membuat anak terlambat mandiri adalah orangtua yang cenderung terlalu protektif. Mereka merasa tidak nyaman melepaskan anaknya. Padahal, setiap anak mampu mengukur, seberapa jauh ia dapat mengontrol diri sendiri. Sebegaimana missal saat berada di ketinggian tertentu, anak mempunyai insting dasar untuk bertahan dan tidak melompat. Seharusnya biarkan anak melakukan hal yang diinginkannya, tetapi tetap harus diawasi. Berdasar hal tersebut para santri didiik dengan pola disiplin yang melatih karakter kemandirian para santri dan santriwati. Tentu dengan pola perlakuan yang berbeda antara santri dan santriwati dalam hal-hal yang bersifat prinsipil.

Bagi anak-anak seumuran sekolah menengah pertama di Pondok Pesantren Nihayatul Amalm Rawamerta yang baru saja lulus dari sekolah dasar pada awal mula tinggal di pondok pesantren jauh dari orang tua yang disayangi memiliki kesulitan dalam beradaptasi kehidupan di pondok pesantren. Namun seiring dengan berjalannya waktu, dengan keistimewaan pondok pesantren santi-santri yang pada awalnya tidak betah tinggal di pondok pesantren lamalama mereka betah hidup mandiri dengan segala hiruk pikuk kebersamaan dengan santri lainnya. Padahal pada dasarnya hampir seluruh santri tidak memiliki hubungan keturunan yang sama antara satu yang lain. Dalam hitungan minggu para santri dapat hidup bersama dalam suka dan duka di pondok pesantren. Ujian terberat bagi mereka memulai kehidupan baru jauh dari segala fasilitas yang dimiliki orang tua mereka. Tahap inilah yang harus dihadapi seorang santri yang kelak akan menjadikan mereka santri yang berkarakter Islami dengan mental yang kuat sebagai pemuda penerus tombak estafet bangsa Indonesia.

\section{Disiplin Waktu}

Kata 'disiplin' sendiri berasal dari bahas Latin yaitu 'discipline' yang artinya latihan akan kesopanan dan kerohanian juga sebagai pengembangan kepribadian. Sikap disiplin dapat muncul sebagai bentuk usaha kita dalam memperbaiki diri sebagai individu yang taat akan aturan yang berlaku. Untuk lebih lengkapnya, mari kita simak pengertian disiplin menurut para ahli berikut ini.

Suharsimi Arikunto (1980: 114). Disiplin adalah kepatuhan seseorang dalam mengikuti 
peraturan atau tata tertib karena didorong oleh adanya kesadaran yang ada pada kata hatinya tanpa adanya paksaan dari pihak luar. Adapun menurut Sanjaya (2005: 9). Disiplin adalah hal yang sangatlah diperlukan bagi setiap siswa, dengan adanya disiplin belajar, tujuan pendidikan akan lebih mudah tercapai.

Jadi, dari beberapa pendapat di atas dapat disimpulkan bahwa disiplin yaitu suatu rasa taat pada nilai yang dipercaya sebagai pertanggung jawaban individu. Tentu sikap ini patuh pada pengendalian dan pengawasan.

Dalam sehari semalam kegiatan santri di Pesantren Nihayatul Amal Rawamerta tentu nya sudah di bagi-bagi waktunya 8 jam untuk sekolah 8 jam untuk mengaji 8 jam untuk istirahat. Maka dari itu santri setiap harinya di harapkan bisa dan tau waktu waktu tertentu untuk istirahat mengaji dan lain-lain. Sehingga dengan pola disiplin yang di terapkan, santri kelak dalam kehidupan sehari-hari di masyarakat atau di mana saja mampu menerapkan kedisiplinan yang telah mendarah daging di dalam dirinya. Di rumah, sekolah, jalan raya, tempat kerja, dan sebagainya. Khususnya disiplin dalam beribadah. Pondok Pesantren Nihayatul Amal menekankan disiplin ibadah bagi para santri santriwatinya.

Aktifitas santri di Pesantren tidak pernah putus selama 24 Jam, merekan mengikuti kegiatankegiantan Pesantren yang telah di buat oleh organisasi atau pengasuh santri. Maka dari itu, hidup di Pesantren pastilah hidup melelahkan. Kelelahan akan terasa nikmat jika santri berada di asrama dan beristirahat. Kata guru kami, lauk yang paling enak adalah lapar. Kasur yang paling empuk adalah lelah. Santri adalah manusia tangguh dan tidak cengeng. Hidup dimana saja bumi memanggil.

\section{Hormat terhadap Guru (Tadzim)}

Guru adalah orang yang telah mengajarkan kita dengan berbagai ilmu pengetahuan dan mendidik kita sehingga menjadi orang yang mengerti dan dewasa. Walau bagaimana pun tingginya pangkatatau kedudukan seseorang, dia adalah bekas seorang pelajar dan tetap berhutang budi kepadagurnya yang pernah yang pernah mendidik pada masa dahulu.

Dalam dunia pesantren, menghormati atau memuliakan guru sering disebut dengan kata bahasa Arab dengan kata (tadzim). Ta'dzim dalam bahasa inggrisnya adalah "respect" yang mempunyai makna sopan-santun, menghormati dan mengagungkan orang yang lebih tua atau yang dituakan. Menurut W.J.S. Poerwadarminta (1976:995) dalam kamus umum bahasa Indonesia mengatakan bahwa sikap ta'dzim adalah perbuatan atau prilaku yang mencerminkan kesopanan dan menghormati kepada orang lain terlebih kepada orang yang lebih tua darinya atau pada seorang kyai, guru dan orang yang dianggap dimulyakan. Menurut Syeikh Salamah dalam Kitab Jauharul Adab (1967 : 3-4) ciri-ciri sikap ta'dzim adalah sebagai berikut;

a) Selalu mengucapkan salam ketika bertemu dengan guru.

b) Mengerjakan pekerjaan yang membuatnya senang.

c) Senantiasa menundukkan kepala ketika duduk didekat guru.

d) Ketika bertemu guru di jalan senantiasa berhenti di pinggir jalan seraya menaruh hormat kepadanya.

e) Selalu mendengarkan ketika guru menerangkan seraya mencatat.

f) Selalu menaruh hormat kepada siapapun.

g) Menjaga nama baik guru dimanapun berada.

Dalam I minggu sekali diadakan pengajian rutin khusus untuk santri dalam mempelajari kitab 
Ta'limul Muta'alim yang isinya kiat menjadi santri yang mendapatkan ilmu yang barokah dan manfaat. Dan karakter menghormati Guru atau kyai (tadzim) ini sudah turun temurun dari dahulu sampai generasi yang sekarang sampai jadi ciri khas santri tunduk kepada Kyai-nya. Contoh sederhana ketika seorang santri di panngil oleh kyai ke rumahnya santri tersebut duduk di lantai dan kyai di kursi. Santri menjawab pertanyan kyai dengan menundukan kepala karena Tadzim.

Kedudukan guru adalah sejajar dengan kedudukan kedua orang tua. Karena jika orang tua dalah orang yang telah membesarkan kita dengan tenaga dan harta, maka guru adalah orang yang telah membesarkan kita dengan ilmu-ilmunya. Kita juga berkewajiban hormat dan berbakti kepada guru sebagaimana wajibnya berbakti kepada orang tua. Amirul mukminin Ali bin abi talib pernah berkata sebagai berikut.

"aku adalah hamba sahaya orang yang telah mengajarkan satu huruf, terserah padanya aku mau dijual, dimerdekakan ataupun tetap menjadi hambannya"

Syaikhaz-zarnuji dalam kitab Ta'lim Muta'allim menjelaskan tentang bagaimana cara seorang murid menghormati gurunya antara lain tidak boleh berjalan di depan gurunya ,tidak boleh duduk di kursi guru. IImu tidak kan dapat di peroleh secara sempurna kecuali dengan di iringi dengan sifat tawaduk murid terhadap gurunya, karena keridaan guru terhadap murid akan memebantu proses penyerapan ilmu. Tawaduk murid terhadap guru merupakan cermin ketinggian sifat mulia murid. Sifat tunduk kepada guru justru merupakan kemuliaan dan kehormatan baginya Dalam sebuah syair dikatakan sebgai berikut

$$
\text { ان المعلم والطبيب كلهما \# لـ ينصحان ادا هما لم يكرما }
$$

"Sesungguhnya Guru dan Dokter, keduanya tidak akan memberikan nasehat (menyembuhkan penyakit), apabila keduanya tidak dimuliakan (tidak ditercaya, tidak dihargai) oleh murid atau pasiennya"

Adapun sikap menghormati guru (tadzim) yang dipraktekan para santri santriwati di Pondok Pesantren Nihayatul Amal sebagaimana dipelajari dalam kitab Ta'lim Muta'alim dapat tunjukan melalui perilakuperilaku santri santriwati berikut :

a) Apa bila bertemu mengucapkan salam dan mencium tangan guru sebagai bentuk ikraman (memuliakan)

b) Apa bila diajak bicara memperhatikan

c) Bersikap rendahhati (tawadu) di hadapan guru

d) Memperhatikan pelajaran yang di berikan dan melaksanakan nasehatnya

e) Tidak menyakiti hati guru dengan perbuatan mau pun ucapan

f) Tidak duduk di atas kursi guru

g) Menghormati keluarga guru (suami atau istri atau anak guru tersebut)

Ada juga kisah yang begitu menghormati guru nyaitu kisah imam syafi'l sebagi berikut : Dikisahkan ,imam syafi'l yang sedang mengajar santri-santri di kelas, tiba-tiba di kejutkan kedatangan dengan seseorang berpakaiaan lusuh ,kumal, dan kotor. Seketika itu imam syafi'l mendekati dan memeluknya. Para santri kaget dan heran melihat perilaku gurunya itu. Mereka bertanya: "siapa dia wahai guru, sampai engkau memeluknya erat-erat .padahal ia kumuh, kotor, dan menjijikan ?" imam syafi,I menjawab : "ia guruku. la telah mengajariku tentang perbedaan antara anjing yang cukup umur dengan anjing yang masih kecil. Pengetahuan itulah yang membuatku bias menulis buku fiqh ini."sungguh mulia akhlak imam syafi'l. ia menghormati semua guru-gurunya ,meskipun dari masyarakat biasa.

Jadi secara umum ciri-ciri dari sikap ta'dzim santri-santriwati Pondok Pesantren Nihayatul Amal 
adalah Bila dihadapan guru selalu menundukkan kepala dengan niat hormat, mendengarkan perkataanperkataan guru, menjalankan perintahnya, menjawab ketika ditanya, merendahkan diri kepadanya, menjaga nama baik guru, menghormati keluarga guru dan lainlain.

\section{Kesederhanaan}

Pondok Pesantren telah mengajarkan kepada santri akan kesederhanaan, khususnya di pesantren Nihayatul Amal Rawamerta. Sekali lagi sederhana bukan berarti miskin. Santri melakukan segalah hal untuk kelangsungan hidupnya di pesntren, seperti membersihkan kamar, merapihkan lemari, membersihkan lingkungan Pesantren, makan siangmalam dengan tahu-tempe. Artinya, para santri menerima hal-hal tersebut tidak dengan instan dan tinggal pakai,tinggal bersih. Namun, merekalah yang melakukan segalah hal dan makan yang cukup sederhana.

Hidup sederhana tidak berarti hidup dalam kesengsaraan, kemiskinan, kemelaratan dan serba kekurangan. Kesederhanaan merupakan pola pikir dan pola hidup yang proporsional, tidak berlebihan dan mampu memprioritaskan sesuatu yang lebih dibutuhkan. Kesederhanaan ialah kemampuan untuk ikhlas menerima yang ada, berusaha untuk berlaku adil dan bersyukur atas setiap rezeki yang diberikan dengan tetap menggunakannya pada hal-hal yang bermanfaat dan berarti. Kemampuan itulah yang memberikan manfaat dan menjadi energi dalam kehidupan kita. Kesederhanaan adalah hal penting dalam hidup dan kehidupan. Jiwa sederhana santri terbentuk bila dibina sejak dini. Sedehana bukan berarti miskin. Sederhana mengajarkan seseorang paham akan aspek kehidupan. Sederhana dalam kebutuhan primer, kebutuhan sekunder Dan kebutuhan lain-lain nya.
Dalam sehari-harinya terlihat santri santriwati tidak dituntut memakai pakaian atau perhiasan berlebihan. Dalam lingkungan satu pesantren tidak menyediakan fasilitas yang super lengkap seperti di hotel. Tentu dengan alat seadanya mereka tetap bisa melakukan kegiatan seperti memasak yang masih memakai tungku bagi santri salafi.

Seluruh stakeholder Pondok Pesantren Nihayatul Amal terlihat dalam keseharian tidak tampak bergaya hidup hedonis yang mengedepankan busana dengan segala pernak-perniknya. Rata-rata bergaya hidup sederhana. Dengan demikian hal tersebut dapat dijadikan contoh bagi para santri santriwati untuk hidup sederhana. Karena sederhana merupakan gaya hidup bukan berarti kondisi sebenarnya dari apapun yang dimiliki.

\section{Kebersamaan dan kekeluargaan}

Kata "Kebersamaan" terasa begitu familiar di telinga kita, khususnya bagi mereka yang tergabung dalam sebuah komunitas atau organisasi. Tapi terkadang individu didalam kelompok tersebut tidak tahu atau bahkan melalaikan arti makna dari kebersamaan. Mengapa rasa kebersamaan begitu penting dalam sebuah organisasi, ikatan, group atau komunitas? Kata "Kebersamaan" memiliki makna sebuah ikatan yang terbentuk karena rasa kekeluargaan/persaudaraan, lebih dari sekedar bekerja sama atau hubungan profesional biasa.

Kebersamaan memiliki empat unsur yang harus diciptakan dan dijaga oleh setiap individu yang tergabung didalamnya:

I. Sehati \& Sepikir (Satu Visi)

2. Tidak egois

3. Kerendahan hati

4. Kerelaan berkorban

Dari hasil observasi, tampak kebersamaan para santri dalam kehidupan amat erat hidup bersama 
dengan teman-teman sejawatnya. Santri santriwati hidup dalam nuansa kekeluargaan yang kental dengan ilmu dan kepedulian. Perbedaan asal daerah, kaya atau miskin tidak tampak dalam kehidupan para santri. Kesedihan kepedihan para santri jauh dari orang tua sanak keluarga tidak terlalu tampak dalam senyuman keceriaan para santri. Tak lepas dari kesederhanaan tentu juga Kekeluargaan yang erat di internalisasikan pada santri.

Dalam satu kamar mereka saling bahu membahu menolong temannya yang kesusahan kebersamaan mereka terlihat ketika ada masalah yang harus di selesaikan bersama. Kamar santri merupakan miniature kehidupan bermasyarakat. Jika dipimpin oleh pemimpin yang baik, warga kamar mendukung segala hasil musyawarah, berkerjasama gotong royong membangun atmosfir kamar yang baik, maka kehidupan dalam bermasyarakat kelak dalam skala besar akan baik pula. Beda hal jika terjadi sebaliknya. Kebersamaan dan kekeluargaan santri santriwati kental terlihat manakala santri santriwati dalam kegiatan kerjasama, makan bersama, mengantri makan/mandi, bermain bersama dalam olahraga atau lainnya, suasana tidur bersama dalam satu kamar lebih dari 10 orang. Dalam hal ini terlihat sangat harmonis kekeluargaan dan kebersamaan para santri di moment santri santriwati makan bersama dalam satu nampan. Hal ini biasa dilakukan minimal dua orang dalam satu nampan/piringn dalam lauk apapun. Dengan riang gembira santri santriwati makan bersama dalam satu wadah sembari membicarakan topik-topik pembicaraan khas anak-anak remaja. Bahkan bagi santri salaf mereka untuk makan sehari-hari. santri-santri tersebut memasak sendiri, membeli bahan-bahan makanan sendiri, mengumpulkan uang sendiri dengan temantemannya dan menjadwal bagia siapa yang bertugas untuk memasak pada waktu tersebut.

\section{KESIMPULAN}

Pondok Pesantren Nihayatul Amal termasuk dalam kategori pondok pesantren yang mengutamakan Pendidikan Agama Islam dalam tipologi pondok pesantren. Adapun peranan Pendidikan Agama Islam di Pondok Pesantren Nihayatul Amal sangat penting dalam proses internalisasi karakter-karakter baik (good character) bagi santri santriwati. Dengan mengutamakan substansi utama dalam pondok pesantren untuk tafaqquh fii ad diin (mempelajari ilmu agama) Pondok Pesantren Nihayatul Amal berdiri kokoh dengan memperkuat pendidikan agama Islam para santri dalam ranah penguasan kitab-kitab klasik yang disusun oleh cendikiawan-cendikiawan muslim di seantero dunia dengan memperkuat pendalaman ilmu alat (tata bahasa dalam bahasa Arab) seperti Nahwu dan Sharaf dengan berbagai macam cabangnya. Dengan penguasaan ilmu alat tersebut, santri-santri mampu membedah kitab-kitab klasik. Sehingga dalam proses panjangnya terinternalisasikan karakter-karakter mulia seperti Mandiri, disiplin, hormat kepada guru, kesederhanaan dan kebersamaan/kekeluargaan dalam diri santri-santriwati. Proses internalisasi tersebut beratahap tidak kata instant.

\section{UCAPAN TERIMA KASIH}

Puji syukur ke hadirat Allah SWT karena atas limpah rahmat dan hidayah-Nya, Laporan Kemajuan Hibah Penelitian berjudul "Peranan Pendidikan Agama Islam Dalam Upaya Internalisasi Karakter Di Pondok Pesantren (Penelitian Di Pondok Pesantren Nihayatul Amal Rawa Merta Karawang) " dapat diselesaikan.

Untuk itu, peneliti ingin mengucapkan terimakasih pada seluruh elemen yang terlibat dalam penyusunan yakni 
I. Bapak Rektor Universitas Singaperbangsa Karawang berserta jajarannya,

2. Ketua Lembaga Penelitian dan Pengabdian Masyarakat Universitas Singaperbangsa Karawang, Bapak Dr. Nelly Hartini, S.E.M.M. beserta jajarannya

3. Dekan Fakultas Agama Islam Universitas Singaperbangsa Karawang, Bapak Dr. $\mathrm{H}$. Amirudin, Drs., M.Pd

4. Seluruh dewan pengajar Pondok Pesantren Nihayatul Amal Rawamerta Karawang

5. StafPengelolaAnterior JurnalUM Palangkarayabesertajajarannya.

Tim peneliti menyadari Penelitian yang telah dibuat masih jauh dari sempurna. Untuk itu, tim peneliti terbuka atas segala masukan yang membangun demi terciptanya perbaikan dan perubahan yang diperlukan. Masukan dapat disampaikan secara tertulis kepada tim peneliti sehingga terdapat rekam dan catatan untuk dapat menyusun revisi yang diperlukan. Demikian yang dapat tim penulis sampaikan. Akhir kata, tim peneliti menyampaikan banyak terima kasih atas waktu dan perhatian yang diberikan selama proses penelitian.

\section{REFERENSI}

Ahmad Tafsir, 2008, StartegiMeningkatkanMutu PAI, Bandung: Maestro

Andayani Dian dan Abdul Majid. 2011, Pendidikan, KarakterPerspektif Islam, Bandung: PT RemajaRosdakarya

Baharuddin dan tim penulis, 2011, Dikotomi Pendidikan Islam; Historisitas dan Implikasi Pada Masyarakat Islam, cet.2, Bandung, PT Rosdakarya,

Depdiknas, KamusBesarBahasa Indonesia
Dharma Kesuma, et. all., 2011, PendidikanKarakter "KajianTeoridanPraktik di Sekolah" Bandung: PT RemajaRosdakarya,

Djatnika, Rahmat, 1987, SistemEthika Islam, Surabaya, Pustaka Islam,

DzakiahDrajat, dkk. 1992, IlmuPendidikan Islam, Jakarta; BumiAksara. cetke -2,

E.Mulyasa, 2012, Manajemen Pendidikan Karakter, Bandung : PT Rosda Karya,

Hasbullah, Dasar-dasarilmupendidikan, (Jakarta: PT Raja GrafindoPersad, 2005) cet ke-4,

Hery Nur Aly, 1999, Ilmu Pendidikan Islam, Jakarta: Logos,

J. Moleong, Lexy., 2013, Metode penelitian kualitatif, Bandung : Remaja Rosdakarja,

James Caplin, 1993, Kamus Lengkap Psikologi, Jakarta: PT Raja Grafindo Persada

MohArdani, 2005, AkhlakTasawwufNilai - nilaiAkhlak / Budi PekertiDalamIbadatdanTasawwuf, Jakarta : Cv : KaryaMulia,

Moh.Ardani, 2005, Akhlak-Tasaowufnilai nilaiakhlak/Budi

PekertidalamibadatdanTasawuf, Jakarta: CV KaryaMulia,

Pusat Pembinaan dan Pengembangan Bahasa Departement Pendidikan dan Kebudayaan, 1989, Kamus Besar Bahasa Indonesia, Jakarta: Balai Pustaka,

Ramayulis, 2004, IlmuPendidikan Islam, (Jakarta, KalamMula, cetke- 4

Sahilun A. Nasir, 1999, PerananPendidikan Agama TerhadapPemecahanproblemaRemaja, Jakarta :KalamMulia,

Suyadi, StrategiPembelajaranPendidikanKarakter, Bandung :RosdaKarya

Thomas Lichona,Educating for character . 
ZakiahDrajat, 2001, Kesehatan Mental, Jakarta

:TokoGunungAgung,

ZakiyahDarajat, 1995, MetodelogiPengajaran Agama

Islam, Jakarta :BumiAksara,

ZamakhsyariDhofier,

1982

TradisiPesantrenStudiTentangPandanganHid

upKyai, (Jakarta: LP3ES

Zuhairini, 1983, MetodikKhususPendidikan Agama,

Surabaya: Usaha Nasional

\section{Jurnal}

Ramdhani, M. T., Lastaria, L., \& Ariyadi, A. (2019). Pembelajaran Ekonomi dalam Islam pada Materi Mudharabah di Pondok Pesantren. Anterior Jurnal, 19(I), 32-40.

Norcahyono, N., \& Ariyadi, A. (2019). Pandangan Majlis Tarjih Muhammadiyah Kalimantan Tengah Tentang Tindakan Euthanasia Dalam Pendidikan Waris Islam. Tunas: Jurnal Pendidikan Guru Sekolah Dasar, 5(1), 50-61. 